\title{
アルミナセラミックスの破壊靭性に関する研究
}

\author{
大原秀晴・横堀寿光・野尻啓市 \\ (東北大学 工学部 機械工学第 II 学科)
}

\section{Experimental and Analytical Studies on Fracture Toughness of Alumina Ceramics}

\author{
Hideharu OHARA, A. Toshimitsu YOKOBORI, Jr. and Keichi NOJIRI \\ ( $\left.\begin{array}{l}\text { Department Mechanical Engineering II, Tohoku University } \\ \text { Aramaki, Aoba, Sendai-shi } 980\end{array}\right)$
}

Experimental and analytical studies on fracture toughness of alumina ceramics were carried out, and the following results and conclusions were obtained.

(1) The fracture toughness obtained by conventional fracture mechanics approach is apparent one, and increases with an increase of precrack length and shows a constant value in the range of larger crack length.

(2) This characteristics was explained by the interaction between a main precrack and inherent microcracks or voids near the crack tip.

(3) The microcrack is often induced near the tip of the notch during cutting under green sheet. The microcrack results in the deviation from the linear relation between load versus displacement, and decreases the fracture toughness.

(4) If we avoid the elimination of factors (2) and (3) would enhance the fracture toughness and decrease its scatter.

[Received January 26, 1987 ; Accepted July 16, 1987]

Key-words : Alumina ceramics, Fracture toughness, The effect of crack length, Specimen size, Notch, Crack, Defect

\section{1. 緒 言}

セラミックス材料の強度は, 空孔, 内部欠陥等の影響 を受けるため，精度の良い評価は困難である．特に，連 続体力学に基づく破壊力学的手法がこのような, 空孔内 部欠陥を含む材料によ゙の程度適用できうるかを明確にす ることは，セラミックスを構造材料として実用化する場 合に重要な問題となろう.

そこで, 本論文では, 多結晶アルミナセラミックス材 料を用いて破壊時の限界応力拡大係数（破壊䩲性）に及 ぼす, き裂長さ, 試験片大きさの影響について実験的に 調べ,それを統計的に解析して破壊強度の評価を行った。

\section{2. 供試材，実験方法}

供試材としては, 表 1 に示す多結晶アルミナセラミッ クス（IC 基板用）を用いた. 試験片はグリーンシート 時にプレスによって切欠きを導入し，それを焼結して図 1 及び表 2 に示す試験片に作製した。このような通常の 切欠き導入法によると, 図 2 に示すように先端半径 $\rho \simeq 0$, 切欠き開き角 $\theta$ は $40^{\circ} \sim 75^{\circ}$ の範囲のものが得ら れた. しかし,この $\rho$ 及び $\theta$ の範囲では応力特異性に ついては $1 / \sqrt{r}$ 特異性が保たれている11. したがって, この切欠き長さはき裂長さとして取り扱ってよいことに なる.実験としては 3 点曲げ試験を行い, 負荷速度は $0.5 \mathrm{~mm} / \mathrm{min}$ とした。本来セラミックス材料は porosity
を含み厳密な意味での連続体ではない，この材料に連続 体であることを前提とした破壊力学を適用するには, porosity に比べてき裂が十分長く，き裂に対して母材が 近似的に連続体亡みなしうることが必要条件となってい る. したがって, どの程度のき裂長さから, セラミック スに含まれるボイドとの相互作用をうけるのかを明らか

Table 1. Chemical composition and mechanical properties of materials use.

\begin{tabular}{|l|c|c|}
\hline \multirow{2}{*}{ Composition } & $\mathrm{Al}_{2} \mathrm{O}_{3}$ & $96 \%$ \\
\cline { 2 - 3 } & $\mathrm{SiO}_{2}$ & \\
& $\begin{array}{l}\mathrm{MgO} \\
\mathrm{CaO}\end{array}$ & $4 \%$ \\
\hline Average grain size & $3.65 \times 10^{-3} \mathrm{~mm}$ \\
\hline Specific gravity & 3.7 \\
\hline Bending strength & $27 \mathrm{~kg} / \mathrm{mm}^{2}$ \\
\hline Compressive strength & $200 \mathrm{~kg} / \mathrm{mm}^{2}$ \\
\hline
\end{tabular}

Table 2. Dimension of the specimen.

\begin{tabular}{|c|c|c|c|}
\hline $\begin{array}{c}\text { Specimen } \\
\text { No. }\end{array}$ & $\begin{array}{c}\text { Width } \\
\mathrm{B}(\mathbf{m})\end{array}$ & $\begin{array}{c}\text { Crack length } \\
\mathbf{a}(\mathbf{m})\end{array}$ & $\begin{array}{c}\text { The number } \\
\text { of specimens }\end{array}$ \\
\hline 1 & $12.5 \pm 1.5$ & $0.04 \sim 0.02$ & 47 \\
\hline 2 & 15.2 & $0.09 \sim 0.12$ & 10 \\
\hline 3 & $18.5 \pm 1.5$ & $0.04 \sim 0.20$ & 47 \\
\hline 4 & 25.2 & $0.09 \sim 0.12$ & 10 \\
\hline 5 & $30.5 \pm 1.5$ & $0.04 \sim 0.20$ & 57 \\
\hline 6 & $35.5 \pm 0.5$ & $0.09 \sim 0.15$ & 20 \\
\hline
\end{tabular}




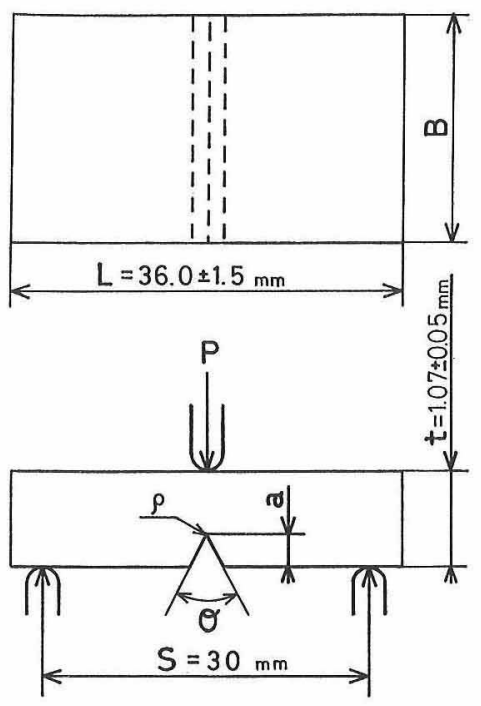

Fig. 1. Specimen dimension.

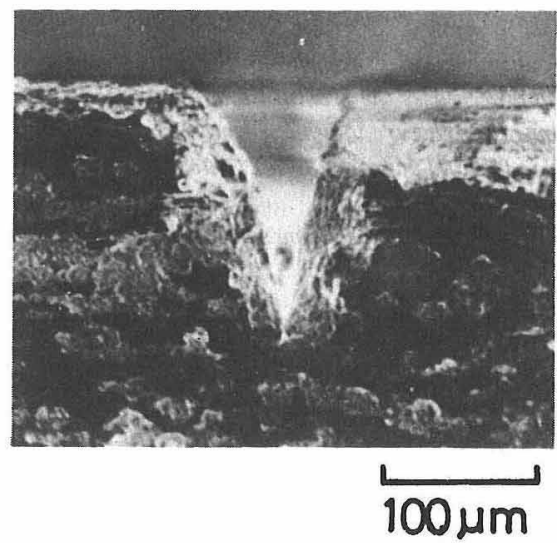

Fig. 2. The notch introduced (SEM).

にすることが重要である，本論文では，このような考え 方に従って，種々にき裂長さを変えて，母材を連続体と 考えて破壊䩲性値をもとめ, ビの程度のき裂長さから， porosity との相互作用により，き裂に対して母材を連続 体と考えられなくなるかを調べた．

そのように考えると， $K_{\mathrm{c}}$ は（1）式のように表され $ろ^{2)}$.

$$
K_{\mathrm{c}}=\sigma_{\mathrm{f}} \sqrt{\pi a} F\left(\frac{a}{t}\right)
$$

ここで, 破壊応力 $\sigma_{\mathrm{f}}$ 及び, $F(a / t)$ はそれぞれ $(2)$ 式，(3) 式で与えられる.

$$
\begin{aligned}
& \sigma_{\mathrm{f}}=\frac{2 P_{0} S}{2 B(t-a)^{2}} \\
& \begin{aligned}
F\left(\frac{a}{t}\right)= & 1.22-1.40 \times\left(\frac{a}{t}\right)+7.33 \times\left(\frac{a}{t}\right)^{2} \\
& -13.08\left(\frac{a}{t}\right)^{3}+14.0 \times\left(\frac{a}{t}\right)^{4}
\end{aligned}
\end{aligned}
$$

ここで, $a=$ 切欠き (き裂) 長さ, $t=$ 板厚, $P_{0}=$ 破壊

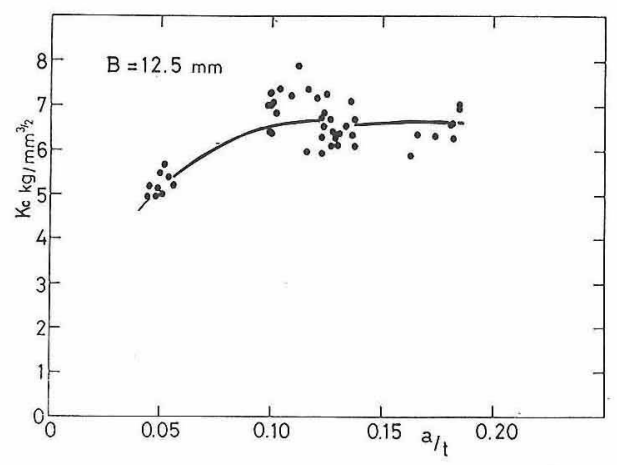

(a)

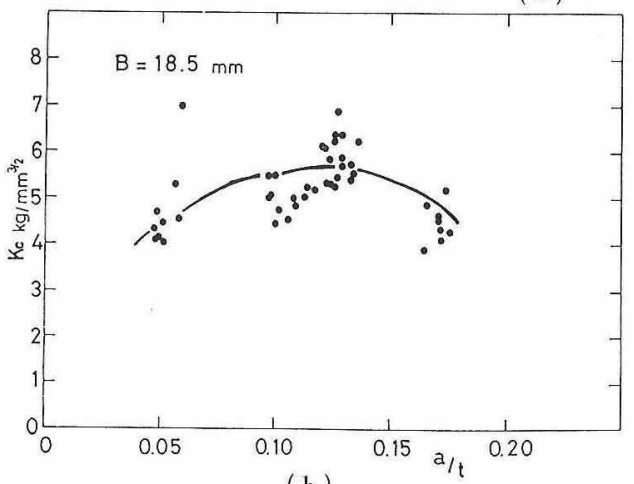

(b)

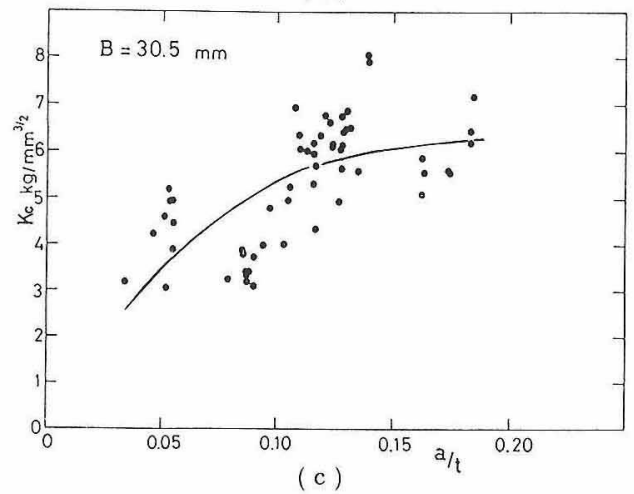

Fig. 3. (a) The relation between $K_{\mathrm{c}}$ and $a / t, B=$ $12.5 \mathrm{~mm}$,

(b) The relation between $K_{c}$ and $a / t, B=18.5 \mathrm{~mm}$,

(c) The relation between $K_{\mathrm{c}}$ and $a / t, B=30.5 \mathrm{~mm}$.

荷重， $S=$ スパン長さである. 表 1 に示す試料はすべて （4）式を満たしている.すなわち，連続体であるとす れば平面ひずみ破壊靶性値となる条件を満たしてい $ろ^{3)}$.

$$
B, a \geqq 2.5\left(\frac{K_{\mathrm{IC}}}{\sigma_{\mathrm{YS}}}\right)^{2}
$$

ただし， $\sigma_{\mathrm{Ys}}$ は単純引張降伏応力である，またき裂長さ の方も $a / t \leqq 0.6$ であって, (3) 式の適用範囲を満た している．板幅 $B$ としては， 6 種類を用い，そのうち， $B=12.5,18.5$, 及び $30.5 \mathrm{~mm}$ の場合については, き 裂長さ $a$ も種々に変えてそれぞれ $47 \sim 57$ 本用いた. 


\section{3. 実験結果}

\section{1. 破壊靭性值 $\boldsymbol{K}_{\mathrm{c}}$ と, き裂深さ $\boldsymbol{a}$ との関係}

図 3 (a), (b), (c) には, $B=12.5,18.5,30.5 \mathrm{~mm}$ の場合についての $K_{\mathrm{c}}$ と $a / t$ との関係の実験結果をしめ した. 本結果から， $K_{\mathrm{c}}$ は $0.05 \leqq a / t \leqq 0.12$ において $a / t$ の増加とともに若干増加する傾向を示している. $B$ $=12.5,30.5 \mathrm{~mm}$ については, $a / t>0.12$ において, 一定值に飽和する傾向を示す. 他方, $B=18.5 \mathrm{~mm}$ では, $a / t \geqq 0.13$ にて $K_{\mathrm{c}}$ は減少する傾向を示した. この $K_{\mathrm{c}}$ の減少する現象は, 図 4 に示す 3 点曲げ武験における荷 重-変位曲線が $\beta$ 形曲線の特性を示し, 直線的なぜい性 破壊の荷重変位曲線を示さなかったことに対応している と考えられる.なお， $\beta$ 形曲線をしめす理由については 3.2 節に調べてある. $B=18.5 \mathrm{~mm}, a / t \geqq 0.13$ の結果 を除いて実験結果をまとめると図 5 のようになる.図 6 には $K_{\mathrm{c}}$ が $a / t$ の増加によって, 増加する領域内の $a / t=0.1 \pm 0.005$ における $K_{\mathrm{c}}$ と $B$ との関係を示して おり, $B$ の増加とともに $K_{\mathrm{c}}$ 值が減少することが分かる.

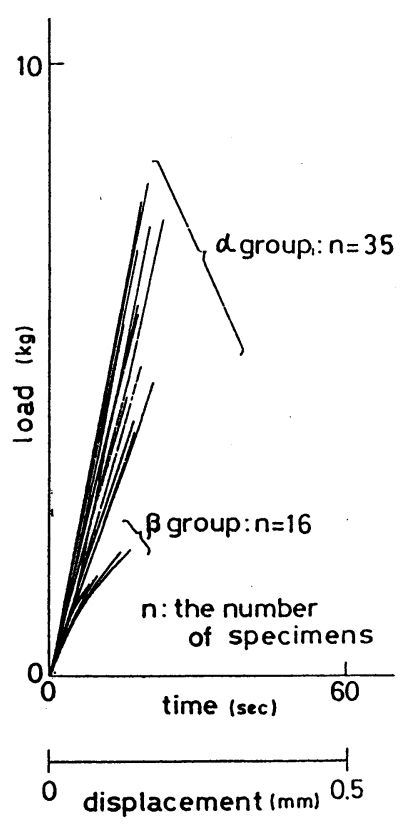

Fig. 4. The relation between applied load $P$ and displacement $u$.

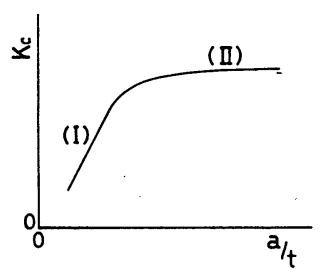

(a)

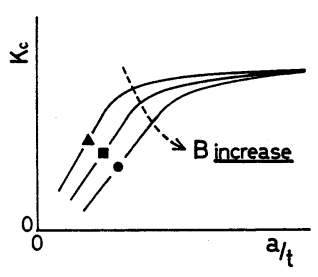

( b )
Fig.5. Schematic illustration of the experimental relation between $K_{\mathrm{c}}$ and $a / t$ obtained.
それに対して $K_{\mathrm{c}}$ 值が $a / t$ に対して一定となる $a / t=$ $0.13 \pm 0.005$ においては，図7に示すように $B \leqq 32 \mathrm{~mm}$ において $K_{\mathrm{c}}$ 值は $B$ に依存せず一定值となる．したがっ て, $a / t \geqq 0.125, B \leqq 32 \mathrm{~mm}$ においては， $K_{\mathrm{c}}$ の値は, $B, a / t$ によらず一定となり，すなわち，いわゆる平面 ひずみ破壊勒性值が得られることになる.

\section{2 破断面観察}

破断面を図 8 (a)，(b)，(c) に示す. 破断面は図 8 (a) に示すように, 切欠き底から明視野領域として観察され る粒界割れ領域を経て粒内割れに遷移しているものと図 8 (b) に示すような粒内割れのみの場合とが観察され た.しかし，この破断面の相違は直接強度には影響を与 えていないようである.なお，試料の一部には，切欠き 先端延長方向に図 8 (c) に示すようなマイクロクラック が観察されるものがあった。これは前報 ${ }^{4}$ で示したよう に,グリーンシート時に刃物にて切欠きを導入したとき の圧縮応力に起因して生じた図 9 に示すマイクロクラッ クに対応するものと考えられる．このマイクロクラック の存在によって, 母材の強度低下, コンプライアンスの 増加をきたし図 4 に示した $\beta$ 形曲線の特性を示したと 思われる. 図 $3(\mathrm{~b})$ に示した $B=18.5 \mathrm{~mm}, a / t \geqq 0.13$

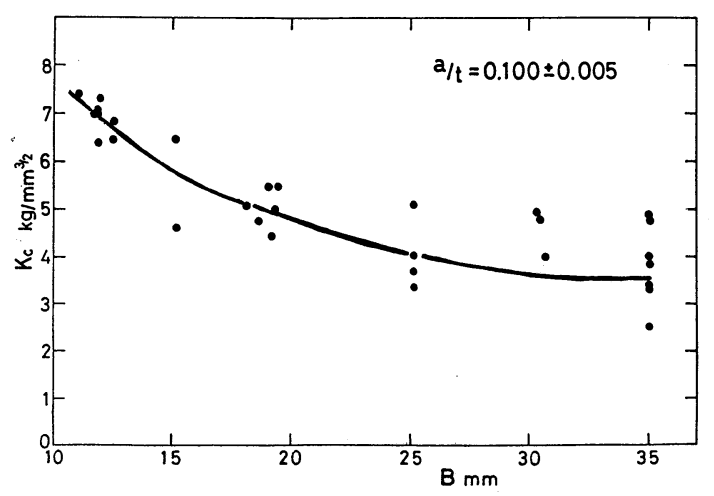

Fig. 6. The relation between $K_{\mathrm{c}}$ and specimen width B. $a / t \doteqdot 0.1$

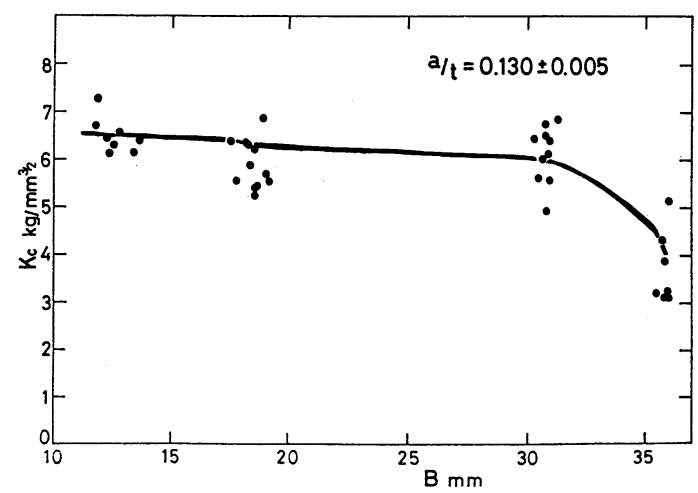

Fig. 7. The relation between $K_{\mathrm{c}}$ and specimen width B. $a / t \doteqdot 0.13$ 


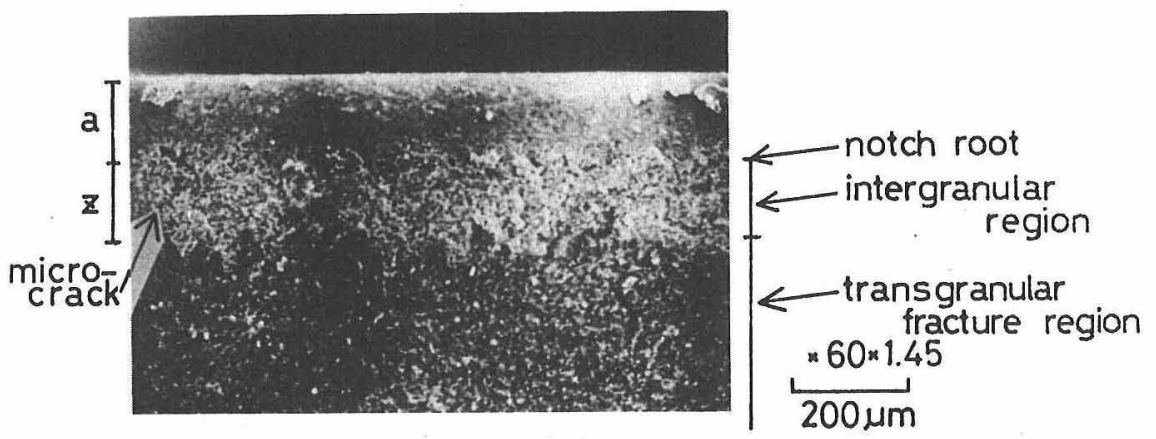

(a)

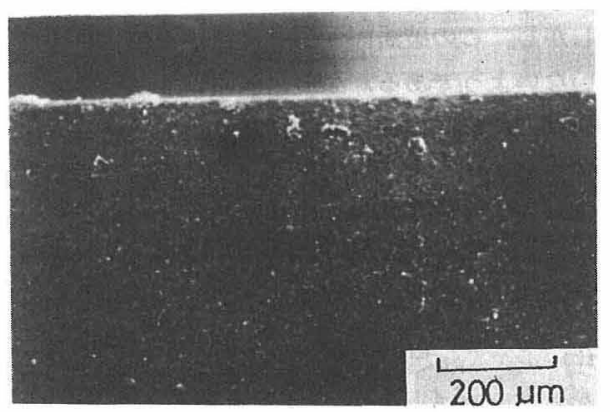

( b )

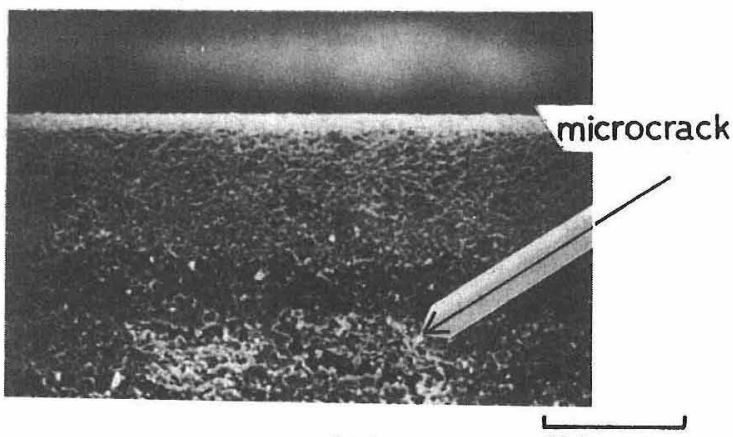

(c)

$100 \mu \mathrm{m}$

Fig. 8. The fracture surface (SEM).

(a) The case in which grain boundary crack initiated near the crack tip. $B=12.70 \mathrm{~mm}, \quad a=0.133 \mathrm{~mm}$

(b) The case in which transcrystalline crack initiated near the crack tip. $B=12.05 \mathrm{~mm}, \quad a=0.198 \mathrm{~mm}$

(c) The case in which microcrack initiated in the extended direction in advance of the crack length.

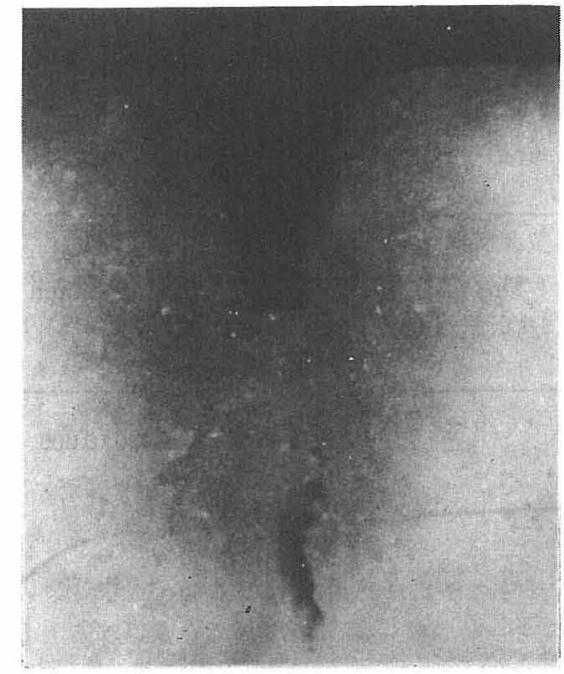

Fig. 9. The microcrack initiated in the extended direction in advance of notch (crack) during the notch being provided in green sheet state.

$\mathrm{mm}$ の領域で $K_{\mathrm{c}}$ 值が低下したのは，すべて $\beta$ 形曲線の 特性を示しており,このような切欠き導入時に生じたマ イクロクラックの存在がその原因と考えられる.

\section{4. 破壊䩲性 $\boldsymbol{K}_{\mathrm{c}}$ と $\boldsymbol{a} / \boldsymbol{t}$ との関係}

導入付与したき裂（切欠き）を連続体中の単独き裂と みなしてもとめた破壊勒性 $K_{\mathrm{c}}$ は主き裂長さ $a$ が短いと きは，図3，図 5 にしめしたように $a$ の減少とともに低 下するという結果を得た． 2 章に述べたように，本実験 は（4）式なる平面ひずみ破壊鞁性値としてみたすべき， $B, a$ の条件は満足している，したがって破壞勒性の実 験值 $K_{\mathrm{c}}$ 值が $a$ の低下とともに低下するという原因は， 他に存在することになる，その原因は，主き裂が短くな ると，応力を負荷される場合に，主き裂の長さに対し， その先端近傍に存在するボイド, ないし微視き裂の長さ の影響が無視できなくなることにあると考えられる。す なわち，主き裂とボイドないし微視き裂との相互作用力 が強くなったことに起因するものと考えられる.

そこで，いま図 10 に示すように長さlの主き裂とボ イドないし微視き裂（長さ $r$ のき裂とみなし）との相 互作用を考慮した $b$ 点での応力拡大係数として（6） 式が導かれる5 ${ }^{5}$.

$$
\begin{aligned}
& K_{1}(b)=\sigma \sqrt{\pi l} \sqrt{1+\frac{r}{t_{0}}} \\
& \cdot\left[1-\left(1+\frac{t_{0}}{l}\right) \frac{E_{1}(k)-E_{2}(k)}{E_{1}(k)}\right]=\alpha_{1} \sqrt{\pi l} \sigma
\end{aligned}
$$


ここで,

$$
\alpha_{1} \equiv \sqrt{1+\frac{r}{t_{0}}}\left[1-\left(1+\frac{t_{0}}{l}\right) \frac{E_{1}(k)-E_{2}(k)}{E_{1}(k)}\right]
$$

$l=a-b, \quad t_{0}=b-c=$ 主き裂とボイドないし微視き 裂との対向先端距離，また， $E_{1}(k), E_{2}(k)$ はそれぞれ 第 1 種, 第 2 種完全だ円積分であり, $k=$

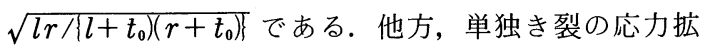
大係数 $K_{0}$ は $(7)$ 式で与えられる.

$$
K_{0}=\sqrt{\pi l} \sigma
$$

(6) 式と（7) 式の比をとると（8) 式を得る.

$$
\frac{K_{0}}{K(b)}=\frac{1}{\alpha_{1}}
$$

( 8 ) 式による $K_{0} / K(b)$ を $l / r$ に対して計算すると 図 11 のようになる. $\alpha_{1}>1(t \rightarrow \infty$ にて 1$)$ であるから, （８）式から分かるように, 相互干渉のある場合には実 際の応力拡大係数 $K(b)$ は単独き裂の場合の応力拡大 係数 $K_{0}$ よりも大きくなることが分かる. ところで, こ のように近接微視き裂が存在する場合の破壊応力 $\sigma_{\mathrm{bf}}$

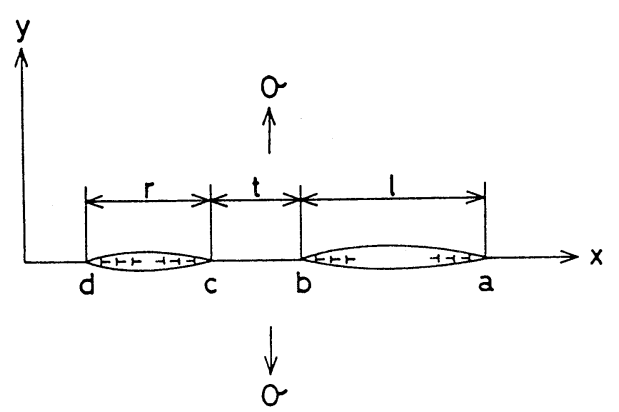

Fig. 10. The interaction between unequal size, two coplaner cracks under tensile stress. $l=$ main crack length, $r=$ microcrack length, $t_{0}=$ the distance between the two opposed tips of each crack.

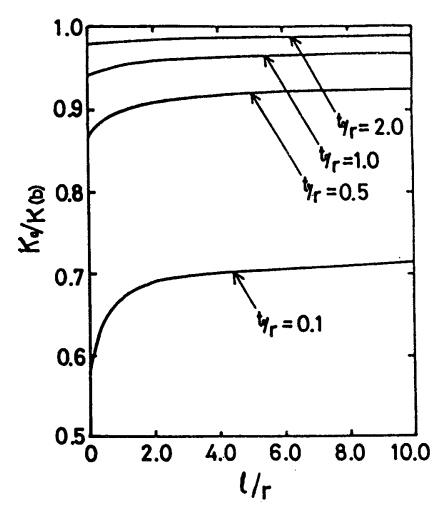

Fig. 11. The ratio of $K_{0} / K(b)$ versus $l / r$. $K_{0}=$ stress intensity factor for an isolated crack, $K(b)=$ stress intensity factor at the opposed tip of the main crack for two coplaner crack, $l=$ length of main crack, $r=$ length of microcrack, $t_{0}=$ the distance between the two opposed tips of each crack
は, 次のように，近接微視き裂の存在しない単独き裂の 場合の破壊応力 $\sigma_{0 \mathrm{of}}$ よりも低下していることがしめされ る.すなわち，いま，破壊のクライテリオンとして線形 力学においての常套手段のようにエネルギー条件を用い る次の限界条件を得る.

$$
K_{\mathrm{Ic}}(b)=K_{\mathrm{oc}}=\text { 一定 }
$$

ここで, (6) 式より破壊時の $K(b)$ として

$$
K_{\mathrm{Ic}}(b)=\alpha_{1} \sqrt{\pi l} \sigma_{\mathrm{bf}}
$$

のように表わされ, また, $(7)$ 式より, 破壊時の $K_{0}$ として,

$$
K_{0 \mathrm{c}}=\sqrt{\pi l} \sigma_{0 \mathrm{f}}
$$

のように表わされる（10）式と（11）式を（9）式に 代入すると $\sigma_{\mathrm{bf}}$ と $\sigma_{0 \mathrm{ff}}$ の比は

$$
\frac{\sigma_{\mathrm{bf}}}{\sigma_{0 \mathrm{f}}}=\frac{1}{\alpha_{1}}
$$

となる。すすなわ， $\alpha_{1}>1$ であるから (12) 式から $\sigma_{\mathrm{bf}}$ $<\sigma_{0 f}$ となることが分かる. さて, いわゆる従来の線形 破壊力学の方法で実験的に求める破壊勒性値としては, 上述の相互作用を考え入れていないわけである. した がって, 応力拡大係数の頃のうちで $\sigma$ に掛かる係数之 しては単独き裂としての係数（すなわち，この場合には, ( 7 ) 式の $\sqrt{\pi l})$ を用いているのである. すなわち, 破 壊䩲性值 $K_{\mathrm{c}}$ としては

$$
K_{\mathrm{c}}=\sqrt{\pi l} \sigma_{\mathrm{bf}}
$$

として求めていることになる．このような意味で（13） 式は母材を予き裂と相互干渉するようなボイドや空げき を内部に含まない連続体として求めていることになる. したがって,このようにして求めた $K_{\mathrm{c}}$ という值は, 見 掛け上の破壊勒性值ということになる. 言いかえれば

(13) 式で求めた $K_{\mathrm{c}}$ は, 予き裂の長さなどによらない で $\sqrt{l} \sigma_{\mathrm{bf}}$ だけできまるという本来の破壊䩚性ではない. ここで， $\sigma_{\mathrm{bf}}$ は, この場合に実験的に求めた破壊応力で あって,

（11）式と（13）式から（14）式のようになる.

$$
\frac{K_{\mathrm{c}}}{K_{\mathrm{oc}}}=\frac{\sigma_{\mathrm{bf}}}{\sigma_{0 \mathrm{f}}} \leqq \frac{1}{\alpha_{1}}<1
$$

$t_{0} \rightarrow \infty$ にてはじめて $\alpha_{1}=1, K_{\mathrm{c}}=K_{\mathrm{oc}}$ となる.このよう にして連続体中の単独き裂として求めた見掛け上の破壊 鞀性值 $K_{\mathrm{c}}$ は, $(7)$ 式が成立する単独き裂の場合の破 壊勒性值 $K_{\mathrm{oc}}\left(=\sqrt{\pi l} \sigma_{\mathrm{of}}\right)$ の值よりは低くなることが分 かる. しかも $\alpha_{1}$ の值は $(6 \mathrm{a})$ 式, 図 11 に示すように き裂長さ $l$ (本論分では $a$ ) の減少とともに増加するこ とから ${ }^{5)}$, 見掛けの破壊鞀性值 $K_{\mathrm{c}}$ の值がき裂長さ (切 欠き長さ) $a$ の減少とともに低下するという図 3, 図 5 の実験特性が説明される.

\section{5. 破壊勒性値 $K_{\mathrm{c}}$ の平均値と分散の統計的取り扱い} セラミックス材の破壊勒性値 $K_{\mathrm{c}}$ は図 3 などに示した 
ように, ばらつきが大きいので, 統計的処理が必要であ る. 統計的取り扱いにもいくつかの方法がある. 確率過 程としての取り扱いは後報に譲ることにする.ここでは, 平均値特性と分散特性を求めることにした．まず各板幅

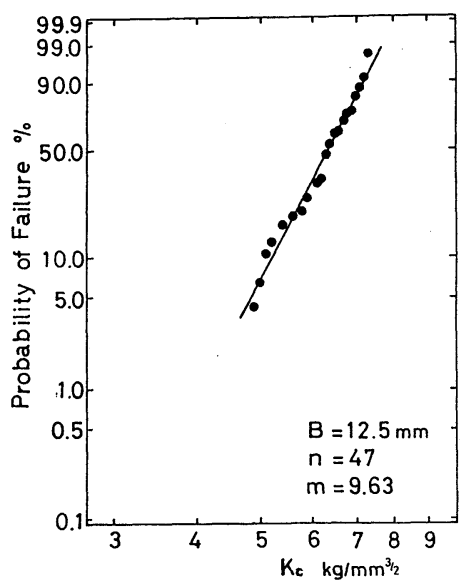

(a)

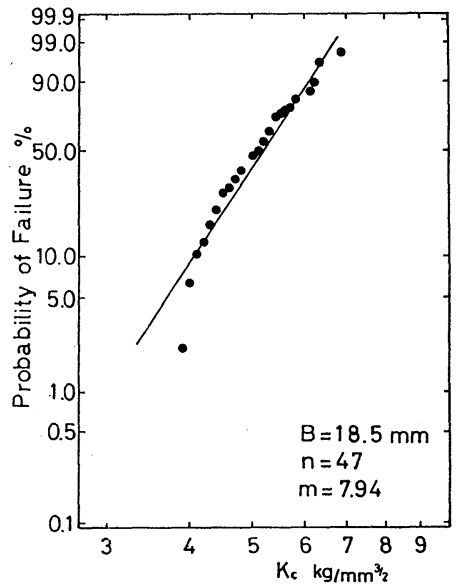

( b )

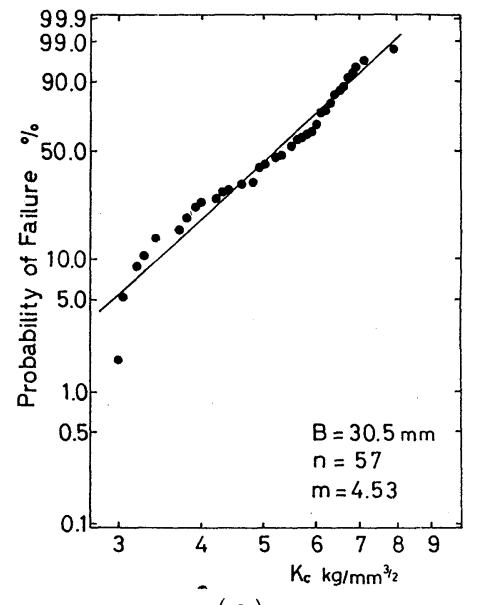

(c)

Fig. 12. Fracture toughness $K_{\mathrm{c}}$ plotted as Weibull paper.
$B$ について実験した。 き裂長さ全範囲にわたる破壊靭 性值 $K_{\mathrm{c}}$ を一つの母集団に属するものとしてワイブル確 率紙にプロットするとそれぞれ図 $12(\mathrm{a}),(\mathrm{b})$, (c) の ようになる. その平均值及び分散を表 3, 図 13 に示す. これらの結果より $B$ 值が増加すると $K_{\mathrm{c}}$ の平均值は減少 しワイブル係数 $m$ 值も小さくなる. 次に $K_{\mathrm{c}}$ が $a$ に依 存する領域 $(a \leqq 0.125 \mathrm{~mm})$ と $a$ に依存しない領域 $(a \geqq 0.125 \mathrm{~mm})$ とが，それぞれ異なる母集団に属す るものとして二つに分けて, 各 $B$ 值について, $K_{\mathrm{c}}$ 值を ワイブル確率紙にプロットしたものをそれぞれ図 14 (a), (b), (c), 図 $15(\mathrm{a}),(\mathrm{b}),(\mathrm{c})$ に, その平均值 と分散を表 3 , 図 16, 図 17 に示す. $a \leqq 0.125 \mathrm{~mm}$ では, 図 14 から $K_{\mathrm{c}}$ はワイブル分布にあまり従わないこと, また，図 16 から， $K_{\mathrm{c}}$ の平均值は $B$ 值の増加とともに $5 \%$ 有意水準にて有意に減少していることが分かる.こ のことは，図 6 に示した $a \leqq 0.125 \mathrm{~mm}$ にて $K_{\mathrm{c}}$ 值が $B$ の増加とともに減少するという実験特性を統計的に明確 にしている. 他方 $a \geqq 0.125 \mathrm{~mm}$ では, 図 15 から $K_{\mathrm{c}}$ 值 はワイブル分布にかなりよく従い，しかも図 17 から $K_{\mathrm{c}}$ 值は，Bによらず一定值をしめすこと，また，ワイブ ル係数も大きくなる（表 3）ことが分かる. 各 $B$ 值に おける $a \geqq 0.125 \mathrm{~mm}$ での $K_{\mathrm{c}}$ の平均値は表 3 から $a \leqq 0.125 \mathrm{~mm}$ のそれに比して有意に増加しており,こ のことは, 図 3 , 図 5 にに示した $K_{\mathrm{c}}$ 值が $a$ の増加とと

Table 3. Mean ualues $\left(\bar{K}_{\mathrm{c}}\right)$ and the dispersion of $K_{\mathrm{c}}\left(\phi^{2}\right)$, and Weibull coefficient $(m)$.

\begin{tabular}{|c|c|c|c|c|}
\hline \multicolumn{2}{|c|}{ Specimen vidth $(m): B$} & 12.5 & 18.5 & 30.5 \\
\hline \multirow{3}{*}{ All specimens } & $\mathrm{m}$ & 9.63 & 7.94 & 4.53 \\
\hline & $\overline{\mathrm{K}} \mathrm{c}$ & 6.27 & 5.11 & 5.01 \\
\hline & $\phi^{2}$ & 0.588 & 0.605 & 1.680 \\
\hline \multirow{3}{*}{$\begin{array}{l}\text { Crack length: } a \\
a \leqq 0.125=\end{array}$} & $\mathrm{m}$ & 6.01 & 10.38 & 4.49 \\
\hline & $\overline{\mathrm{K}} \mathrm{c}$ & 5.95 & 4.68 & 4.39 \\
\hline & $\phi^{2}$ & 1.307 & 0.284 & 1.255 \\
\hline \multirow{3}{*}{$\begin{array}{l}\text { Crack length: a } \\
a \geqq 0.125\end{array}$} & $\mathrm{~m}$ & 18.18 & 7.77 & 8.48 \\
\hline & $\overline{\mathrm{K}} \mathrm{c}$ & 6.46 & 5.31 & 6.02 \\
\hline & $\phi^{2}$ & 0.184 & 0.683 & 0.727 \\
\hline
\end{tabular}

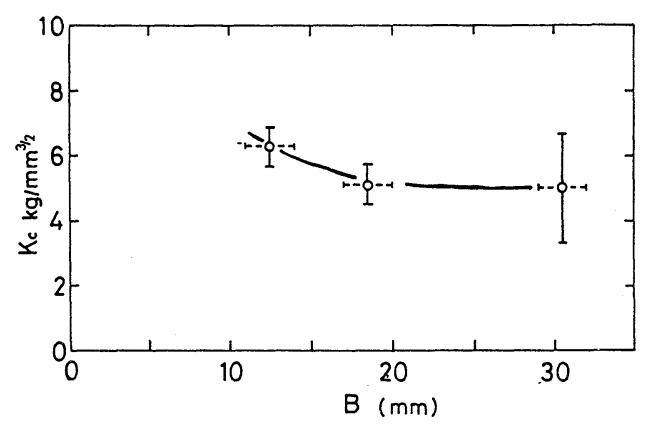

Fig. 13. The relation of mean value of fracture toughness to specimen width $B$. The horizontal dotted line shows the range of the specimen width introduced. 


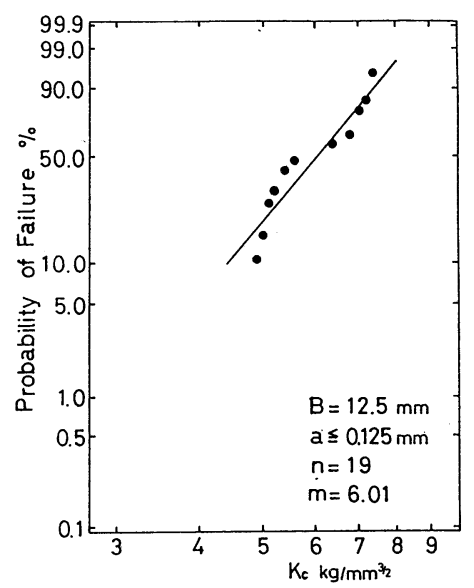

(a)

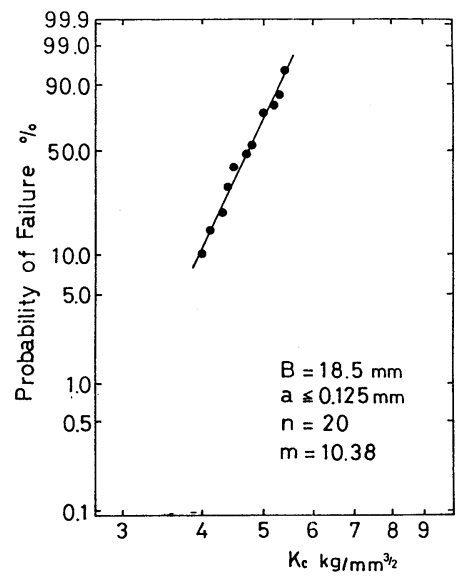

( b )

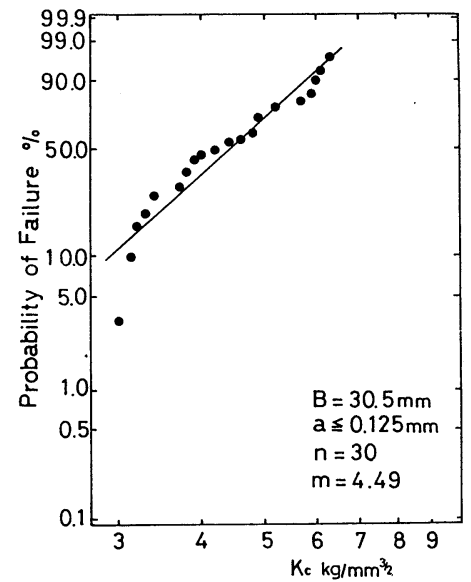

(c)

Fig. 14. Fracture toughness plotted as Weibull paper for $a \leqq 0.125 \mathrm{~mm}$.

もに増加し，一定値に近づくという実験特性を統計的に 明確にしたことになる。

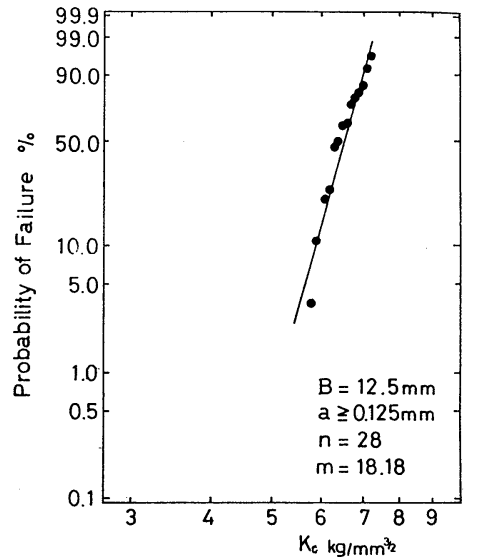

(a)

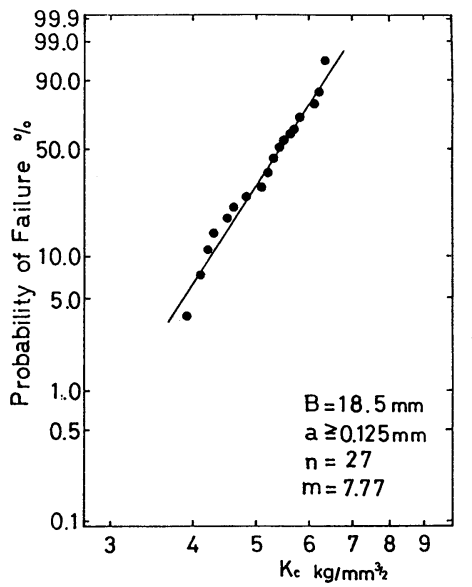

(b)

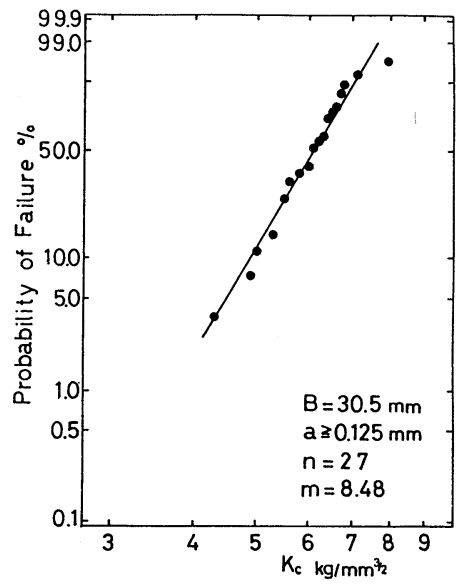

(c)

Fig. 15. Fracture toughness plotted as Weibull paper for $a \geqq 0.125 \mathrm{~mm}$.

\section{6. 結 論}

（1）き裂を連続体中の単独き裂として求めた破壊時 の限界応力拡大係数, $K_{\mathrm{c}}$, すなわち見掛けの破壊靶性 値 $K_{\mathrm{c}}$ は, き裂長さの短い範囲すなわち, $a / t \leqq 0.125$ 


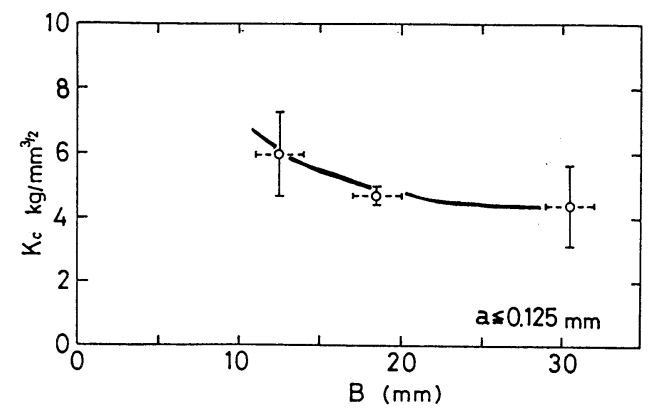

Fig. 16. The relation of mean value of fracture toughness to specimen width $B$, for $a \leqq 0.125 \mathrm{~mm}$. The horizontal dotted line shows the range of the specimen width introduced.

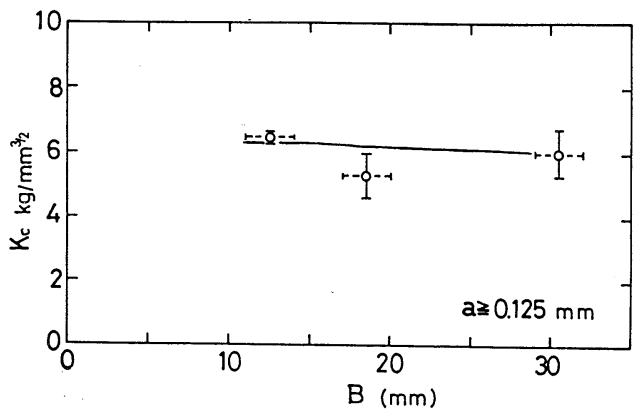

Fig. 17. The relation of mean value of fracture toughness to specimen width $B$, for $a \geqq 0.125 \mathrm{~mm}$. The horizontal dotted line shows the range of the specimen width introduced.

にては $a / t$ の増加とともに増加し，き裂長さが長くな ると，すなわち $a / t \geqq 0.125 に て 一$ 定値に飽和する. ま た $a / t \leqq 0.125$ においては板幅 $B$ の増加とともに $K_{\mathrm{c}}$ 值 は減少する. したがって破壊靶性値が材料固有の一定值 をしめすのは， $a / t \geqq 0.125, B \leqq 32 \mathrm{~mm}$ の範囲である.
この領域での破壊䩲性值 $K_{\mathrm{c}}$ は $4 \sim 7 \mathrm{kgmm}^{-3 / 2}$ であり, その変動幅は全範囲の值を採用した場合の $K_{\mathrm{c}}$ 值のばら つきに比べて小さくなる.

（2） $a / t \leqq 0.125$ で $K_{\mathrm{c}}$ 值がき裂長さ $a$ とともに変 化することは，実験値のばらつきではなくして，アルミ ナセラミックスに含まれる微視き裂ないしボイドと主き 裂との相互作用効果であると考えられる.

（3）切欠き導入時に生ずるマイクロクラックや板幅 $B$ の増加に伴う形状効果も $K_{\mathrm{c}}$ 值を減少させることにな ると考えられる．切欠き導入時にマイクロクラックが生 じた場合, 荷重-変位曲線は, ぜい性破壊に固有な直線 的な荷重-変位特性を示さず, 非線形な荷重-変位特性を 示す.

（4）したがって，結論（2），（3）の原因を取り除 くことによって，本来の $K$ 值を大きくし，かつ，その ばらつきを減少させることができる.

謝 辞 最後に, 本研究に終始御助言, 御助力頂いた, (株) 日立化成工業に謝意を表する。

\section{文献}

1) 淡路英夫, 横堀寿光, 横堀武夫, 日本材料強度学会誌, 20, 24 (1985); A. Awaji, A. T. Yokobori, Jr. and T. Yokobori, Computers \& Structures, Vol.22, No.1 (1986) p. 25

2) H. Tada, "The Stress Analysis of Cracks Hand book", Del Research Corporation, Hellertown, Pa., U.S.A. (1973).

3) Annual Book of ASTM Strandards Part 31 (1970) E 399, p. 911.

4）大原秀晴, 横堀寿光, 野尻啓市, 内藤紳司，窯協，93， 81-88 (1985).

5) T. Yokobori, M. Ohashi and M. Ichikawa, Rep. Inst. Str. Frac. Mat. Tohoku Univ. (東北大学材料強度研究 施設報告), Vol. 1, No.2 (1965) 33; A. Kamei and T. Yokobori, ibid., Vol.10, No.2 (1974). 